Joanna Pitura

Uniwersytet Pedagogiczny

pitura@ poczta.onet.pl

\title{
ZASTOSOWANIE BLOGA WE WSPIERANIU REFLEKSJI STUDENCKIEJ PODCZAS PRAKTYK PEDAGOGICZNYCH
}

\author{
Implementing blogs to support student reflection during \\ the teaching practicum
}

The article concerns pre-service English language teacher training and discusses some results of an on-going action research project, the aim of which is to investigate a way of supporting student reflection while they do obligatory teaching practice in Polish state schools. The paper presents the design of the "Develop by Blogging" intervention, as well asits pilot implementation. Preliminary findings suggest that the intervention has the potential to create time and space for reflection on individual professional experience and can constitute a chance for enhancing reflection among pre-service teachers.

Keywords: reflection, practicum, Learning Design, Learning Design Studio, blog

Słowa kluczowe: refleksja, praktyki, projektowanie dla uczenia się, studio projektowania dla uczenia się, blog

\section{W prowadzenie}

Kształcenie nauczycieli języków obcych postrzegane jest jako proces konstruowania wiedzy zawodowej, czemu towarzyszy zdobywanie praktycznego doświadczenia w szkole w ramach praktyk pedagogicznych oraz rozwijanie refleksyjności ( (Jodłowiec, 2005; Zawadzka-Bartnik, 2014; Komorowska, 2015).

${ }^{1}$ W literaturze pojęciu refleksji nauczycielskiej poświęcono już wiele uwagi (np. Gabryś-Barker, 2012; Neofilolog Nr 43/1, 2014). Wobec braku zgodności w rozumieniu 
W procesie tym refleksja odgrywa bardzo istotną rolę. M iędzy innymi pozwala ona nauczycielowi, by zmienił się w - cytując Elżbietę Zawadzką-Bartnik - „nauczyciela kreatywnego i innowacyjnego, świadomego i odpowiedzialnego za wyniki własnej pracy" (2014: 9).

W zamyśle praktyki zawodowe mają stwarzać warunki do takiej zmiany, do pobudzania inicjatywy oraz wglądu we własne działania w sferze profesjonalnej (Zawadzka-Bartnik, 2014; Czura, 2014). Jednak realizacja tych idei w czasie praktyk pedagogicznych jest dość problematyczna. Autorka niniejszej publikacji, pracując z grupami praktykantów jako ich uniwersytecki opiekun dydaktyczny, odczuwała brak czasu i przestrzeni na obserwowanie czy też ewentualne celowe organizowanie takiej aktywności. W rzeczywistości okazywało się bowiem, że - ze względów organizacyjnych i logistycznych - śledzenie refleksji studenckiej, tzn. doświadczeń, wrażeń, odczuć i przemyśleń praktykantów, możliwe było tylko w bardzo ograniczonym zakresie. Równie niesatysfakcjonujący był brak możliwości utrzymania dialogu zarówno z praktykantami, jak i ich opiekunem oraz trudności w przekazywaniu informacji zwrotnej. W konsekwencji stwierdzono, że potencjał, jaki niesie możliwość uczenia się podczas praktyk dzięki dokonywaniu refleksji, był słabo wykorzystywany. Pojawiły się więc pytania o to, jak skuteczniej wspierać refleksję studencką, a w szczególności, kiedy to robić i czego refleksja ta ma dotyczyć.

Odpowiedzi na te pytania można szukać w literaturze mówiącej o zastosowaniu dziennika jako narzędzia do wspierania rozwoju zawodowego nauczycieli, w tym właśnie refleksji nauczycielskiej (np. Gabryś-Barker, 2012). Jednak wykorzystanie tego rozwiązania w praktyce jest dość kłopotliwe. Student każdorazow musiałby przekazywać dziennik, aby opiekun czytał wpisy na bieżąco. Z kolei jednorazowe czytanie dzienników po zakończeniu praktyk nie dawałoby możliwości wejścia na bieżąco w interakcję ze studentami, aby pobudzić ich do przemyśleń czy zainspirować, nie można by też było zaangażować innych studentów w dyskusję.

Wydaje się, iż w rozważaniu omawianego problemu warto skorzystać z badań dotyczą cych projektowania dla uczenia się (ang. Learning Design, tłum. własne) i przyjrzeć się modelowi studia projektowania dla uczenia się (ang. Learning Design Studio, tłum. własne; Mor i Mogilevsky, 2013), w którym świadomie angażuje się nauczycieli w dokonywanie refleksji nad własnym uczeniem się oraz efektami indywidualnych działań pedagogicznych. Obiecujące w kontekście podjętego problemu badawczego były również badania, których wyniki

tego pojęcia, w niniejszym artykule przyjęto ogólną definicję: refleksja nauczycielska to „zastanowienie się nad problemem / sytuacją dydaktyczną i/lub wypowiedź studenta wynikająca z takiego zastanowienia się" (por. http://sjp.pwn.pl/sjp/refleksja;2573649.html). 
Zastosowanie bloga we wspieraniu refleksji studenckiej podczas praktyk...

pokazują pozytywny wpływ blogowania na umiejętności przyszłych i czynnych nauczycieli w zakresie myślenia refleksyjnego, np.: Stiler i Philleo (2003), Yang (2009), Killeavy i M oloney (2010), Luik et al. (2011), Fisher i Kim (2013), Garza i Smith (2015). Jak ujęli to Fisher i Kim: „blogi funkcjonowały jako "urządzenie do myślenia", które wsparło rozwój zawodowy" (2013: 156; tłum. własne). Tak więc można sądzić, że model studia projektowania dla uczenia się (ang. Learning Design Studio) oraz blog mogą mieć potencjał do tego, by stworzyć bardziej angażujące, pobudzające do refleksji środowisko dla współczesnych studentów-praktykantów. Potrzebna jest jednak empiryczna weryfikacja tego przypuszczenia, umożliwiająca ocenę trafności i skuteczności zastosowania tych rozwiązań. Taka ocena byłyby istotna dla działań mających na celu zwiększanie efektywności praktyk, indywidualizację wsparcia, czy też racjonalizację procesu kształcenia przyszłych nauczycieli.

W związku ze zdiagnozowanymi potrzebami zostało zaplanowane badanie mające na celu zaprojektowanie, wdrożenie i ewaluację interwencji dydaktycznej, która tworzyłaby środowisko wspierające studentów filologii angielskiej w dokonywaniu refleksji w trakcie praktyk pedagogicznych. Niniejszy artykuł przedstawia wycinek trwającego projektu, badania w działaniu, w którym omówiony jest etap projektowania i pilotażu interwencji dydaktycznej.

\section{Perspektywa teoretyczna}

U podstaw prezentowanego badania leżą ustalenia psychologii uczenia się, pedeutologii oraz projektowania dla uczenia się (ang. Learning Design).

W ramach psychologii uczenia się, przedstawione badanie odwołuje się do konstruktywistycznych teorii uczenia się - poprzez interakcję społeczną (Wygotski, 1971), praktyczne doświadczenie (Kolb, 1984) oraz refleksję w działaniu, refleksję nad działaniem i refleksję dla działania (Schön, 1983; Farrell, 2007). Jak wyjaśniają Abbie Brown i Timothy Green, w podejściu konstruktywistycznym zakłada się, że w trakcie uczenia się tworzone jest indywidualne rozumienie świata/zjawisk, dla którego bardzo istotna jest interakcja z innymi ludźmi oraz refleksja nad własnym doświadczeniem. W procesie tworzenia nowej wiedzy o tym osobistym znaczeniu wykorzystywana jest wiedza dotychczasowa, która łączona jest z indywidualnie przetwarzanymi informacjami ze środowiska (Brown i Green, 2016: 29-34).

Drugim obszarem, który został wykorzystany w badaniu, jest pedeutologia, dział pedagogiki zajmujący się m.in. kształceniem nauczycieli. Jak już wcześniej wspomniano, w ostatnich latach sporym zainteresowaniem cieszy się badanie zastosowania bloga w procesie kształcenia nauczycieli, także jako narzędzia wspomagającego rozwijanie refleksji nauczycielskiej. Niektórzy badacze 
wskazują, że blogowanie może pomagać w pogłębianiu refleksji i prowadzić do zmian w pracy nauczycieli. Sprzyja temu niewątpliwie charakter narzędzia - wszechstronność, elastyczność i łatwość w zastosowaniu - pozwalający na personalizację uczenia się. Istotne w kontekście tej publikacji jest również to, że blog stwarza wiele możliwości w zakresie komunikacji - umożliwia on dotarcie do szerszego audytorium oraz wspólne dzielenie się wiedzą i doświadczeniem, pozwala na wyrażanie uczuć i emocji, co ma niebagatelne znaczenie, jeśli chodzi o przekazywanie i/lub otrzymywanie informacji zwrotnej czy też poszukiwanie i/lub otrzymywanie wsparcia (Luik et al., 2011; Conole, 2012). Te właściwości bloga mogą być ważne w poszukiwaniu rozwiązań mających na celu wspieranie refleksyjności studentów w trakcie praktyk pedagogicznych.

O ile psychologia uczenia się i pedeutologia są znanymi i uznanymi dziedzinami/działami wiedzy, projektowanie dla uczenia się (ang. Learning Design) jest stosunkowo młodym nurtem. Badacze zwracają uwagę, że nie jest on tożsamy z projektowaniem dydaktycznym (ang. Instructional Design), chociaż przyznają, że praktyki te pod pewnymi względami się pokrywają (M or i Craft, 2012). Projektowanie dla uczenia się (ang. Learning Design) definiowane jest jako:

[M ]etodologia umożliwiająca nauczycielom/projektantom podejmowanie bardziej świadomych decyzji w projektowaniu aktywności edukacyjnych [learning activities], co ma ugruntowanie w wiedzy pedagogicznej i gdzie uwzględnia się efektywne zastosowanie zasobów i technologii. (...) Projektowanie dla uczenia się jako obszar badawczo-rozwojowy zajmuje się gromadzeniem danych empirycznych potrzebnych do zrozumienia procesu projektowania, a także rozwojem wachlarza zasobów edukacyjnych [learning design resources], narzędzi i aktywności (Conole, 2012: 7-8; tłum. własne).

W ramach nurtu projektowania dla uczenia się (ang. Learning Design), interesujący, z punktu widzenia omawianego badania, jest model studia projektowania dla uczenia się (ang. Learning Design Studio). Jest to model wykorzystujący metodę projektu, a podejmowane działania tworzą powtarzalny cykl (M or i Mogilevski, 2013):

1. Pomyśl (ang. imagine; tłum. własne) - identyfikacja problemu, wyzwania edukacyjnego;

2. Zbadaj (ang. investigate; tłum. własne) - zdefiniowanie kontekstu (czynniki materialne, społeczne, itp.), przyjęcie perspektywy pedagogicznej (teoretycznej), poznawanie stosownej literatury;

3. Zainspiruj się (ang. inspire; tłum. własne) - zapoznanie się z przykładami przeszłych innowacji, zastosowanie pomysłów/dobrych praktyk w projekcie; 
Zastosowanie bloga we wspieraniu refleksji studenckiej podczas praktyk...

4. Wyobraź sobie (ang. ideate; tłum. własne) - przyjęcie ostatecznego rozwiązania, przygotowanie scenariusza działania;

5. Przetestuj prototyp (ang. protototype; tłum. własne) - przygotowanie prototypu działania, szybka implementacja;

6. Dokonaj ewaluacji (ang. evaluate; tłum. własne) - ocena projektu w odniesieniu do jego celów, identyfikacja obszarów wymagających poprawy, modyfikacja projektu;

7. Dokonaj refleksji (ang. reflect; tłum. własne) - opis procesu projektowania, nabytego doświadczenia i efektów.

Mor i Mogilevski opublikowali artykuł, w którym przedstawiają wyniki testowania tego modelu na 22 izraelskich studentach. Autorzy konkludują, że:

[m]odel ten może służyć jako rama odniesienia dla tych, którzy chcą wyszkolić edukatorów na takich, którzy potrafią jasno i świadomie podejmować decyzje. $Z$ dobrze zdefiniowanymi zasadami i we wspierającym środowisku nauczyciele mogą zostać lepszymi projektantami dla uczenia się [learning designers]. Pozwala on profesjonalistom w obszarze edukacji łączyć badania naukowe ze swoją praktyką i zdobywać umiejętności potrzebne do identyfikowania wyzwań edukacyjnych oraz opracowywać efektywne sposoby radzenia sobie z nimi (M or i M ogilevski, 2013: 14; tłum. własne).

Warto też dodać, że model studia projektowania dla uczenia się (ang. Learning Design Studio) jest stosowany w praktyce w celu szkolenia czynnych zaw odowo nauczycieli. Przykładem może być szkolenie „Nauczyciele jako projektanci" (ang. Teachers as Designers; tłum. własne) oferowane przez M iędzynarodowe Stowarzyszenie TESOL (ang. TESOL International Association, tłum. własne; http://www.tesol.org/). Autorka publikacji sama wzięła w nim udział i przeszła pełen cykl pracy z modelem studia projektowania dla uczenia się (ang. Learning Design Studio).

M odel studia projektowania dla uczenia się (ang. Learning Design Studio) został wykorzystany do zaprojektowania interwencji dydaktycznej, w której studenci indywidualnie projektują działania dydaktyczne, a następnie je realizują. W cyklu tej interwencji uwzględniono miejsce na refleksję studencką. Jej stymulowaniu sprzyjać ma zastosowanie bloga, który z jednej strony zapewnia studentom miejsce na wypowiedzenie się (zmaterializowanie myśli, refleksji w działaniu, nad działaniem i dla działania), a z drugiej umożliwia obserwację i dostęp opiekunowi dydaktycznemu. Co istotne, takie rozwiązanie pozwala na wchodzenie w interakcję nie tylko z opiekunem dydaktycznym, ale też i z innymi studentami, z czynnymi nauczycielami oraz ze środowiskiem naukowym. Sprzyja ono szerszej wymianie myśli, dzieleniu się różnego rodzaju zasobami (wiedzą, doświadczeniem, 
publikacjami, linkami, itp.), co w efekcie prowadzi do lepszej jakości i szerszego zakresu kompetencji nabywanych w trakcie praktyk.

Poniżej zaprezentowana została konceptualizacja pola badawczego (Rys. 1).

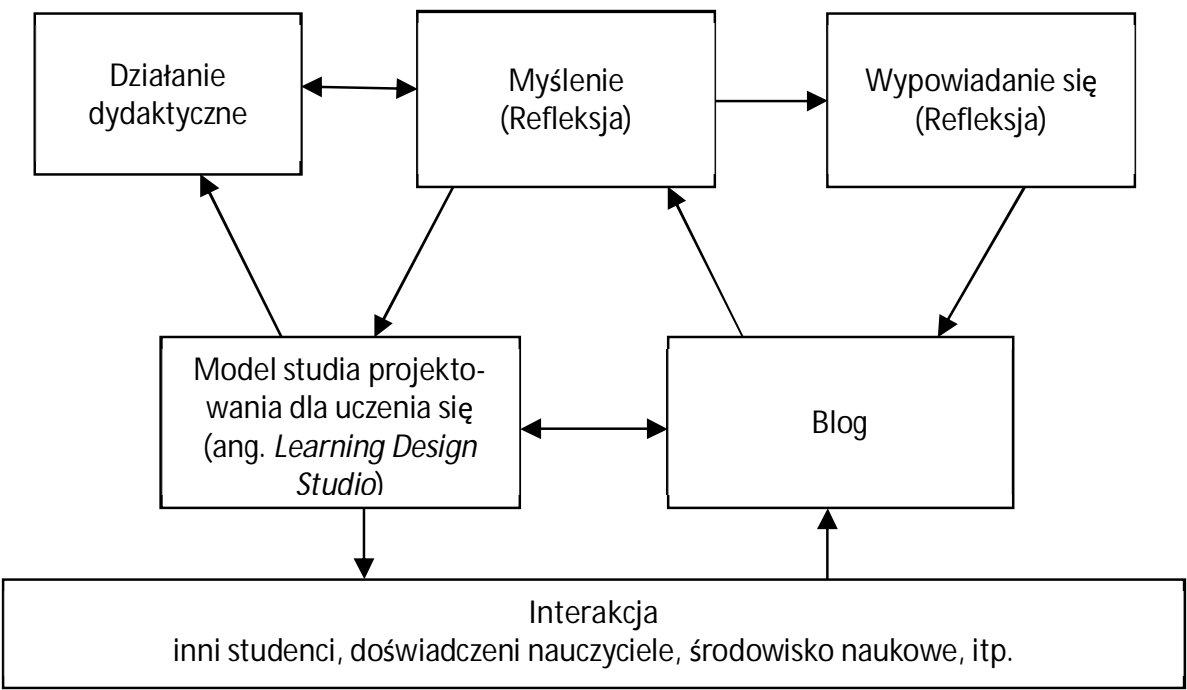

Rysunek 1: Konceptualizacja pola badawczego.

\section{Metody}

\subsection{Typ projektu badawczego}

W badaniu jako paradygmat badawczy przyjęto pragmatyzm, który pozwala na stosowanie metod, technik i procedur badawczych w sposób odpowiadający celom i potrzebom badacza (Creswell, 2013: 36). Ponadto, ponieważ badanie podjęte zostało w odpowiedzi na zidentyfikowane własne problemy dydaktyczne oraz zorientowane jest na ich rozwiązanie, obraną strategią badawczą jest badanie w działaniu (ang. action research), podczas którego nauczyciel-badacz podejmuje działanie i poszukuje rozwiązań mających na celu poprawę sytuacji (procedur dydaktycznych, efektów edukacyjnych) (Wilczyńska i M ichońska-Stadnik, 2010; Gay, Mills i Airasian, 2011).

Aby ocenić adekwatność modelu studia projektowania dla uczenia się (ang. Learning Design Studio) i bloga w tworzeniu środowiska sprzyjającego dokonywaniu refleksji studenckiej, podjęto badanie w działaniu w następujących etapach: 
Zastosowanie bloga we wspieraniu refleksji studenckiej podczas praktyk...

- Etap 1. Diagnoza sytuacji jako problemowej - identyfikacja i zdefiniowanie problemu, poszukiwanie możliwych rozwiązań, ocena podjętych wcześniej działań mających na celu wspieranie praktykantów.

- Etap 2. Planowanie działania zaradczego - zaprojektowanie interwencji "Rozwijaj się poprzez blogowanie" (ang. Develop by Blogging) w trakcie kursu online „Nauczyciele jako projektanci" zorganizowanego przez M iędzynarodowe Stowarzyszenie TESOL (zima 2016).

- Etap 3. Działanie - zastosowanie działania zaradczego w trzech krokach:

1. pilotaż „Rozwijaj się poprzez blogowanie” (ang. Develop by Blogging) w wersji podstawowej (bez etapów „Zainspiruj się" i „Przetestuj prototyp") w trakcie praktyk pedagogicznych luty - marzec 2016;

2. wdrożenie pełnej wersji „Rozwijaj się poprzez blogowanie” oraz ocena interwencji (percepcja studenta) w trakcie praktyk pedagogicznych październik - grudzień 2016;

3. zastosowanie pełnej wersji „Rozwijaj się poprzez blogowanie” oraz ocena interwencji (uczenie się studenta) w czasie praktyk pedagogicznych październik - grudzień 2017.

- Etap 4. Ewaluacja interwencji dydaktycznej - ocena skuteczności zastosowania modelu studia projektowania dla uczenia się (ang. Learning Design Studio) i bloga w tworzeniu środowiska sprzyjającego dokonywaniu refleksji nad działaniami w trakcie praktyk pedagogicznych (Cherry, 2002: 2; Wilczyńska i Michońska-Stadnik, 2010: 151).

\subsection{Wyniki}

\subsubsection{Zaprojektowanie interwencji „Rozwijaj się poprzez blogowanie” (ang. Develop by Blogging)}

W efekcie diagnozy problemu oraz analizy kontekstu zaprojektowano interwencję dydaktyczną, której celem jest wspieranie refleksji studenckiej w małej grupie studentów-praktykantów filologii angielskiej. W ramach interwencji wykorzystano następujące narzędzia online:

1. platforma www.edmodo.com - środowisko do komunikowania się z grupą praktykantów, w którym następuje przekazywanie informacji o zadaniach do wykonania w określonym terminie z adekwatnymi linkami do strony internetowej interwencji developbyblogging.weebly.com;

2. strona developbyblogging.weebly.com - strona internetowa interwencji, gdzie opisane są zadania, zawarte szczegółowe instrukcje oraz linki do potrzebnych zasobów; 
3. bezpłatny blog www.wordpress.com - miejsce dokonywania refleksji (wyrażania myśli, wymieniania się opiniami, doświadczeniami, itp.) oraz dokumentowania działań studenckich w ramach interwencji.

$Z$ uwagi na fakt, że w semestrze letnim praktyki pedagogiczne trwają krótko, dokonano adaptacji cyklu studia projektowania dla uczenia się (ang. Learning Design Studio). Powstała wersja podstawowa, w której pominięte są etapy „Zainspiruj się" i „Przetestuj prototyp”. W Tabeli 1. zaprezentowano scenariusz zaprojektowanej interwencji.

\begin{tabular}{|c|c|c|c|c|c|c|}
\hline & Przygotowanie & Zadanie 1 & Zadanie 2 & Zadanie 3 & Zadanie 4 & Zadanie 5 \\
\hline $\begin{array}{l}\text { Cel } \\
\text { zadania }\end{array}$ & \multirow{4}{*}{$\begin{array}{l}\text { Krok 1. Rejestra- } \\
\text { cja na www.ed- } \\
\text { modo.com } \\
\text { Krok } 2 . \\
\text { Założenie wła- } \\
\text { snego bloga na } \\
\text { www.word- } \\
\text { press.com }\end{array}$} & $\begin{array}{l}\text { Identyfikacja } \\
\text { problemu w kla- } \\
\text { sie }\end{array}$ & $\begin{array}{l}\text { Analiza problemu } \\
\text { +znalezienie spo- } \\
\text { sobu rozwiązania }\end{array}$ & \begin{tabular}{|l|} 
Zaplanowanie \\
akcji mającej na \\
celu rozwiązanie \\
problemu
\end{tabular} & $\begin{array}{l}\text { Wdrożenie } \\
\text { planu działa- } \\
\text { nia }\end{array}$ & $\begin{array}{l}\text { Refleksja nad } \\
\text { efektami } \\
\text { działania }\end{array}$ \\
\hline \begin{tabular}{|l|} 
Akcja \\
offline
\end{tabular} & & $\begin{array}{l}\text { Obserwacja } \\
\text { klasy }\end{array}$ & $\begin{array}{l}\text { Krok 1. Zdobywa- } \\
\text { nie informacji do- } \\
\text { tyczących pro- } \\
\text { blemu w dostęp- } \\
\text { nej literaturze } \\
\text { Krok 2. Omówie- } \\
\text { nie pomystów } \\
\text { zkolegami lub do- } \\
\text { świadczonymi na- } \\
\text { uczycielami } \\
\text { Krok 3. Wybór } \\
\text { jednego rozwiąza- } \\
\text { nia }\end{array}$ & $\begin{array}{l}\text { Uzupełnienie ta- } \\
\text { beli - co, jak } \\
\text { i kiedy będzie się } \\
\text { działo }\end{array}$ & $\begin{array}{l}\text { Działanie } \\
\text { w klasie }\end{array}$ & $\begin{array}{l}\text { Zastanawia- } \\
\text { nie się nad } \\
\text { swoimi dzia- } \\
\text { taniami w ra- } \\
\text { mach całego } \\
\text { projektu }\end{array}$ \\
\hline \begin{tabular}{|l|} 
Akcja \\
online1 \\
Blogowanie
\end{tabular} & & $\begin{array}{l}\text { Opis zaobserwo- } \\
\text { wanego pro- } \\
\text { blemu }\end{array}$ & $\begin{array}{l}\text { Post 1. Lista roz- } \\
\text { wiązań } \\
\text { Post 2. Publikacja } \\
\text { jednego wybra- } \\
\text { nego rozwiązania }\end{array}$ & $\begin{array}{l}\text { Publikacja planu } \\
\text { działania }\end{array}$ & $\begin{array}{l}\text { Dokumento- } \\
\text { wanie dzia- } \\
\text { tań }\end{array}$ & $\begin{array}{l}\text { Publikacja } \\
\text { myśli i wnio- } \\
\text { sków na } \\
\text { blogu }\end{array}$ \\
\hline $\begin{array}{l}\text { Akcja } \\
\text { online2 }\end{array}$ & & \begin{tabular}{|l} 
Czytanie i kome \\
Otrzymywanie
\end{tabular} & $\begin{array}{l}\text { towanie blogów inn } \\
\text { omentarzy od opiek }\end{array}$ & $\begin{array}{l}\text { Iych praktykantów } \\
\text { una dydaktycznego }\end{array}$ & & \\
\hline
\end{tabular}

Tabela 1: Scenariusz interwencji „Rozwijaj się poprzez blogowanie” (ang. Develop by Blogging).

\subsubsection{Wdrożenie interwencji - pilotaż wersji podstawowej „Rozwijaj się po- przez blogowanie" (ang. Develop by Blogging)}

Celem pilotażu był pierwszy test interwencji, sprawdzenie, czy jest ona odpowiednia dla studentów, czy zadania są zrozumiałe i wykonalne; celem nie była ocena wpływu działania zaradczego na kompetencje praktykantów. U czestniczyły 
Zastosowanie bloga we wspieraniu refleksji studenckiej podczas praktyk...

w nim trzy studentki filologii angielskiej (studia II stopnia, specjalizacja nauczycielska) Uniwersytetu Pedagogicznego w Krakowie, które odbywały obowiązkowe praktyki w szkołach ponadgimnazjalnych w okresie luty - marzec 2016 (4 tygodnie).

Wyniki pokazują, że interwencja „Rozwijaj się poprzez blogowanie” jest sprawna technicznie - poszczególne narzędzia wykorzystane w interwencji działały skutecznie, zadania zostały zrozumiane, zaś komunikacja pomiędzy opiekunem dydaktycznym a praktykantami była efektywna (Rys. 2, Rys. 3, Rys. 4). Jest to satysfakcjonujący rezultat pozwalający na zastosowanie wszystkich narzędzi na następnym etapie badania - wdrożenia pełnej wersji „Rozwijaj się poprzez blogowanie" i poddania interwencji ocenie studentów-praktykantów.

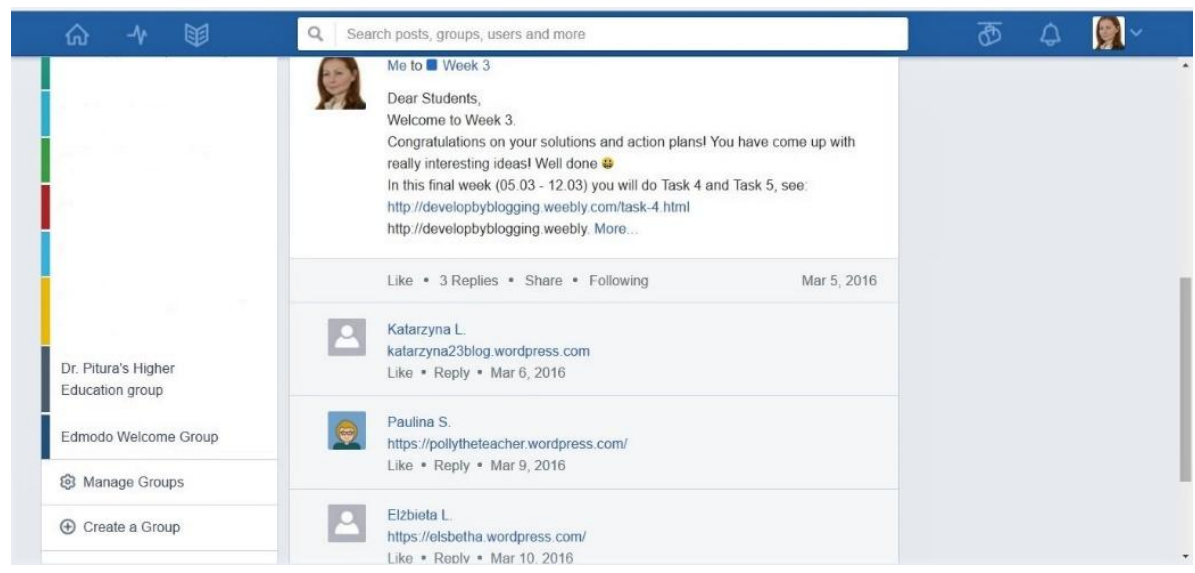

Rysunek 2: Przykład komunikacji na platformie Edmodo.

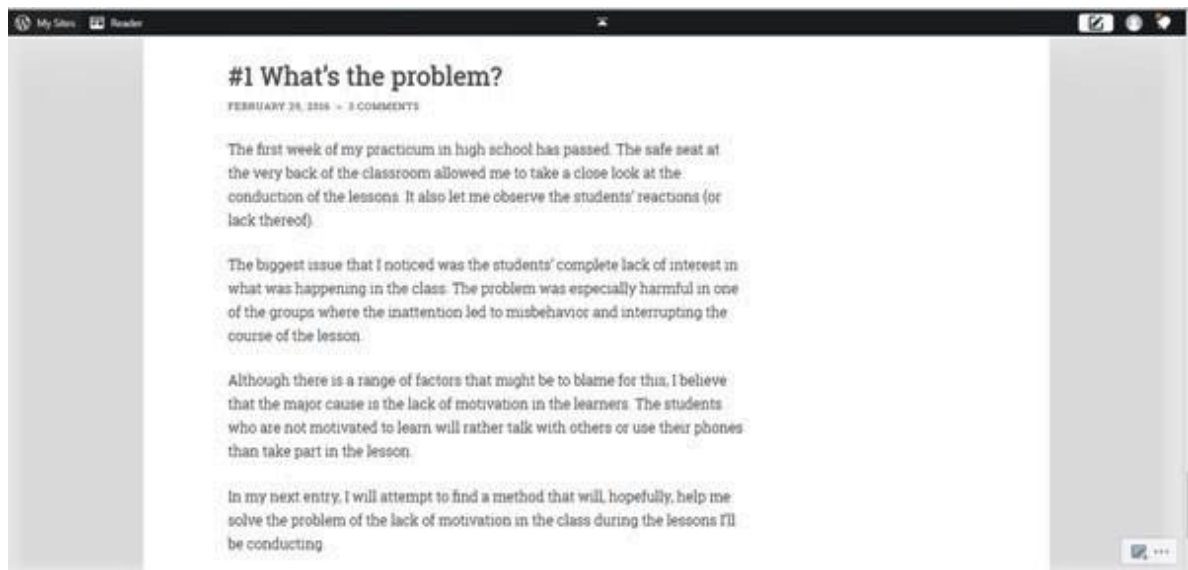

Rysunek 3: Przykład wpisu na blogu praktykanta (https://pollytheteacher.wordpress.com/). 


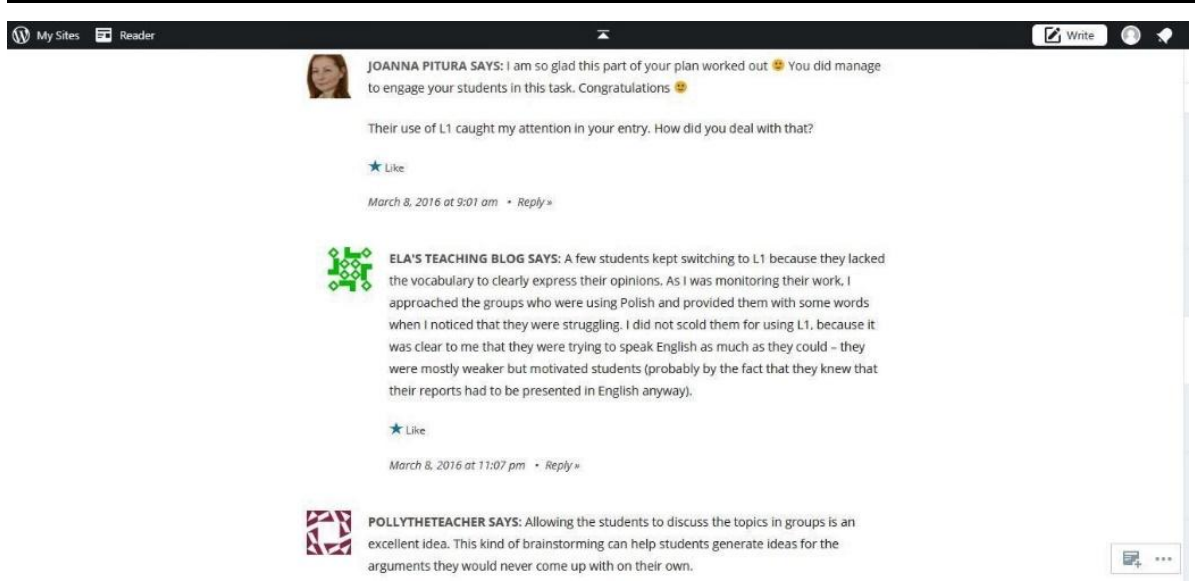

Rysunek 4: Przykład komunikacji z uniwersyteckim opiekunem dydaktycznym i innym praktykantem (https://elsbetha.wordpress.com/2016/03/02/the-solution/\#comments).

Omawiając wyniki pilotażu interwencji, warto również zwrócić uwagę na wyłaniający się na tym etapie badania potencjał projektu „Rozwijaj się poprzez blogowanie”. Po pierwsze, daje się zauważyć, że „Rozwijaj się poprzez blogowanie" tworzy czas i przestrzeń do refleksji w działaniu, refleksji nad działaniem oraz refleksji dla działania - studenci w ramach interwencji identyfikują, analizują i wdrażają rozwiązanie do wybranego przez siebie problemu dydaktycznego, zastanawiają się i wypowiadają na swoich blogach oraz czytają i komentują blogi innych uczestników. Po drugie, „Rozwijaj się poprzez blogowanie" kreuje okazje do uczenia się poprzez działanie - studenci planują i realizują rozwiązania o istotnym dla siebie znaczeniu oraz doświadczają osobistych sukcesów i porażek. Kolejny aspekt to możliwość obserwacji na bieżąco pracy studenta, co pozwala opiekunowi dydaktycznemu na śledzenie indywidualnych problemów studenta-praktykanta w szkole, jego dylematów i decyzji oraz tego, jak sobie radzi z napotkanymi problemami. W końcu, „Rozwijaj się poprzez blogowanie" stwarza dodatkowe okazje do interakcji typu praktykant-praktykant oraz praktykant-uniwersytecki opiekun dydaktyczny.

Poza tymi korzystnymi aspektami, ujawniono też i niedoskonałości interwencji. Nie zaobserwowano wchodzenia studentów w dialog z innymi doświadczonymi nauczycielami, czy też innymi studentami, którzy nie byli członkami grupy praktykantów w interwencji „Rozwijaj się poprzez blogowanie”. Aktywność ta była jednym z istotnych założeń leżących u podstaw projektowanego działania zaradczego. Być może przyczyną były ograniczenia czasowe - zadania wymagały dużego zaangażowania się, zastanowienia, poszukiwania zasobów, planowania i wdrażania pomysłów w klasie oraz regularnej aktywności na 
Zastosowanie bloga we wspieraniu refleksji studenckiej podczas praktyk...

blogu. Jeden miesiąc może być niewystarczający, by w efektywny sposób pracować w ramach takiej interwencji, co zresztą zauważyli sami studenci w bezpośrednich rozmowach z opiekunem dydaktycznym na zakończenie pilotażu.

Pewne zastrzeżenia może też budzić jakość komentarzy na blogach. W zamierzeniu miały służyć one prowadzeniu dyskusji profesjonalnej, być wyrazem refleksji studenckiej, w konsekwencji prowadzącej do konstruowania nowej wiedzy profesjonalnej i zwiększenia efektywności uczenia się podczas praktyk. W chwili obecnej komentarze są raczej ogólnikowe, studenci nie angażują się w dyskusję, publikują tylko jeden komentarz. M ożna mieć wrażenie, że zaangażowali się w nią tylko dlatego, że musieli, że taki był wymóg opiekuna dydaktycznego. Obserwacja ta jest dość zbieżna z wynikami Góreckiej i Nowickiej (2015), które przez jeden semestr badały interakcje studentów filologii romańskiej ( $\mathrm{N}=30)$ o zaawansowanej znajomości języka francuskiego w trakcie prowadzonych dyskusji akademickich na internetowym forum platformy M oodle. Omawiając wyniki, badaczki zauważają, że:

(...) aktywność i zaangażowanie w zadanie realizowane są zbyt często wyłącznie na poziomie wymagań formalnych. Wiąże się to z powierzchownymi działaniami argumentacyjnymi i prowadzi do budowania interakcji, w których rozmówcy nie przejmują odpowiedzialności za formę i przebieg dyskusji (Górecka i Nowicka, 2015: 53-54).

Pojawia się zatem pytanie o źródła tego raczej niewielkiego zaangażowania się w dyskusję profesjonalną na blogu w przypadku praktykantów uczestniczących w omawianej interwencji dydaktycznej. Prawdopodobnym pierwszym powodem jest brak jasnej instrukcji opiekuna dydaktycznego, określającej standardy realizacji tej aktywności. Drugim zaś niewykluczonym powodem jest brak kompetencji studentów w zakresie uczestniczenia w dyskusji profesjonalnej/akademickiej online.

Przed podjęciem realizacji następnego etapu badania w działaniu należy przyjrzeć się omówionym powyżej słabym stronom interwencji, a następnie zmodyfikować ją lub uzupełnić tak, by cel badania mógł być zrealizowany w sposób bardziej satysfakcjonujący.

\section{Podsumowanie}

Sformułowane na tym wstępnym etapie wnioski sugerują, że interwencja dydaktyczna „Rozwijaj się poprzez blogowanie” (ang. Develop by Blogging) może być szansą na wspieranie refleksyjności wśród praktykantów. Z pełną i bardziej zdecydowaną oceną podjętych działań należy jednak poczekać na wyniki zastosowania narzędzi ewaluacyjnych na następnych etapach oraz holistycznej oceny badania. 
Na koniec należałoby zauważyć, że prezentowana interwencja dydaktyczna umożliwia pracę z małą, maksymalnie 6-osobową, grupą. Taki był zamysł przy jej projektowaniu. W pracy z większą grupą o pisane procedury z pewnością mogą jawić się jako czasochłonne z perspektywy opiekuna. W takiej sytuacji projekt „Rozwijaj się poprzez blogowanie” (ang. Develop by Blogging) może stanowić przykład inicjatywy, którą można zaadaptować w sposób adekwatny do istniejących potrzeb. „Rozwijaj się poprzez blogowanie” (ang. Develop by Blogging) może być także inspiracją do projektowania w instytucjach kształcenia i doskonalenia nauczycieli kolejnych interwencji dydaktycznych, które, w oparciu o model studia projektowania dla uczenia się (ang. Learning Design Studio), będą stawiały sobie za cel identyfikowanie indywidualnych problemów dydaktycznych i skuteczne ich rozwiązywanie z zastosowaniem nowych technologii.

\section{BIBLIOGRAFIA}

Brown, A. H. i T. D. Green. 2016. The essentials of instructional design: Connecting fundamental principles with process and practice. New York: Routledge.

Cherry, N. 2002. Action Research: a pathway to action, knowledge and learning. M elbourne: RMIT University Press.

Conole, G. 2012. Designing for learning in an open world. Dordrecht: Springer.

Creswell, J. W. 2013. Projektowanie badań naukowych. M etody jakościowe, ilościowe i mieszane. Kraków: Wydawnictwo Uniwersytetu Jagiellońskiego.

Czura, A. 2014. „Wprowadzenie”. Neofilolog, 43(1): 5-6.

Farrell, T. S. 2007. Reflective language teaching: From research to practice. London: Continuum.

Fisher, L i D. Kim 2013. „Two approaches to the use of blogs in pre-service foreign language teachers' professional development: a comparative study in the context of two universities in the UK and the US". The Language Learning Journal, 41(2): 142-160.

Gabryś-Barker, D. 2012. Reflectivity Pre-service Teacher Education: A Survey of Theory and Practice. Katowice: Wydawnictwo Uniwersytetu Śląskiego.

Garza, R. i S. F. Smith. 2015. „Pre-service teachers' blog reflections: Illuminating their growth and development". Cogent Education, 2: 1066550. http://www.tandfonline.com/ doi/full/10.1080/2331186X.2015.1066550 DW 09.07.2017.

Gay, L. R., Mills, G. E. i P. W. Airasian. 2011. Educational research: Competencies for analysis and applications. Upper Saddle River: Pearson Education.

Górecka, J. i A. Nowicka 2015. „Uczenie się w interakcjach argumentacyjnych a tożsamość ucznia jako rozmówcy”. Lingwistyka Stosowana, 14: 41-55.

Jodłowiec, M. 2005. „Developing a Reflective Practitioner: A Teacher Educator's Perspective". (w) Studies in Teacher Education: Language, Literature, and Culture. (red. M. M isztal i M. Trawiński). Kraków: Wydawnictwo Naukowe Akademii Pedagogicznej, str. 9-16. 
Zastosowanie bloga we wspieraniu refleksji studenckiej podczas praktyk...

Killeavy, M. i A. Moloney. 2010. „Reflection in a social space: Can blogging support reflective practice for beginning teachers?". Teaching and Teacher Education, 26(4): 1070-1076.

Kolb, D. 1984. Experiential Learning. Englewood Cliffs, New York: Prentice Hall.

Komorowska, H. 2015. „Rozwój glottodydaktyki a kształcenie nauczycieli języków obcych". Postscriptum Polonistyczne, 2(16): 11-29.

Luik, P., Voltri, O., Taimalu, M. i K. Kalk. 2011. „On the use of student teacher blogs during teaching practice". Procedia-Social and Behavioral Sciences, 11: 165-169.

M or, Y. i B. Craft. 2012. „Learning design: reflections upon the current landscape”. Research in learning technology, 20 (sup1): 19196.

Mor, Y. i O. M ogilevsky. 2013. "The learning design studio: collaborative design inquiry as teachers' professional development". Research in Learning Technology, 21(1): 22054.

Schön, D. A. 1983. The reflective practitioner. How professionals think in action. New York: Basic Books.

Stiler, G. M. i T. Philleo. 2003. „Blogging and blogspots: An alternative format for encouraging reflective practice among preservice teachers". Education, 123(4): 789-797.

Yang, S. H. 2009. „Using blogs to enhance critical reflection and community of practice". Educational Technology \& Society, 12(2): 11-21.

Wilczyńska, W. i A. M ichońska-Stadnik. 2010. Metodologia badań w glottodydaktyce: Wprowadzenie. Kraków: Avalon.

Wygotsky, L. S. 1971. Wybrane prace psychologiczne. Warszawa: Państwowe Wydawnictwo Naukowe.

Zawadzka-Bartnik, E. 2014. „Refleksja w zawodzie nauczyciela - założenia a realne możliwości realizacji". Neofilolog, 43(1): 7-23.

\section{Netografia}

http://developbyblogging.weebly.com DW 09.07.2017

https://elsbetha.wordpress.com/2016/03/02/the-solution/ \#comments DW 09.07.2017

https://pollytheteacher.wordpress.com DW 09.07.2017

http://sjp.pwn.pl/sjp/refleksja;2573649.html DW 09.07.2017

https:// wordpress.com DW 09.07.2017

http://www.edmodo.com DW 09.07.2017

http://www.tesol.org DW 09.07.2017 